\title{
The Corpus of Life and the Phenomenon of Death in a Traditional Igala (African) Religious Society
}

\author{
Okpe Nicholas Ojoajogwu, Ph.D* \\ Department of Religious Studies, Kogi State University, Anyigba, P. M. B. 1008 Anyigba, Kogi State, Nigeria \\ *Corresponding Author: Okpe Nicholas Ojoajogwu, Ph.D, Department of Religious Studies, Kogi State \\ University, Anyigba, P. M. B. 1008 Anyigba, Kogi State, Nigeria
}

\begin{abstract}
It can be asserted that the most important subject matter among the Igala people like many other societies in Africa circles around life. In other words, everything seems to revolve around projection and preservation of life. For this reason, even when somebody dies, it is believed that he or she is still alive based on legacies, achievements, children etc that the person must have acquired during his earthly life. Thus, people struggle to maintain this essential of what makes a human being whether alive in bodily form or in spirit. And if by any chance, one gives in to bodily decay, ceremonies are arranged to project his continuous existence in the land of the dead. Furthermore, beyond the life of an individual is the community life, which is very important in Igala society. It is believed that nobody can exist in isolation. Hence to be alive means to be part of community undertakings and interactions. This paper looks at the various understanding of corpus of life among the Igala, while examining what is considered enemy of life, which is death. Death, among the Igala, especially that of young people is perceived as anomaly and as such enemy to life. This is because, unlike the elderly that are celebrated by ceremonies when they pass on from bodily existence as forming the ancestors, young people do not easily qualify to be. In this case, the death of a young person is considered a short-change since he or she might not have acquired all that is needed to be considered alive after bodily death. This paper examines the meaning of life as well as its categories, and types of death which is considered enemy of life.
\end{abstract}

Keywords: Life, Death, Igala, Religion, Society

\section{INTRODUCTION}

Igala is a socio-cultural group among the settlers within the confluence of the two Nigerian rivers of Niger and Benue. The name Igala represents the language, the people and the Kingdom itself, and this is the only form that is being used by the people themselves. As a language, Igala belongs to the Kwa sub-group of languages with enormous characteristics of Bantu sub-group of the same Niger-Congo family. The Igala kingdom is marked politically by its well established central administration before the European expedition in Africa. Igala is situated in today's Kogi State in the middle-belt region of Nigeria, and is in fact, the largest ethnic group in the state. They are a people whose social organization and value systems are generally similar and who recognize one paramount king as their political ruler. The 1991 population commission of Nigeria projected Igala to approximately 1.8 million people, which by now (considering the time of writing) could probably be about 2.5 million. Igala is about the 9th largest ethnic group of the about 250 ethnic groups in Nigeria. Igala as a homogenous group inhabits a geographic area with a common language, which though having various dialects nevertheless creates no problem of understanding among them. The cultural patterns of life are identical, closely related, based on similar cults and social institutions. Igala traditional religion believes in one supreme God, known as Ojo, who is responsible for everything in this world and the next. In his studies on Igala people, R. Seton (1930, XXIX), understands Ojo as the creator of everything and lives in the sky, where are many other people. He first put one man and one woman in the world with tree between them...These two lived together, and in the course of time the woman gave birth to twins, who, in turn married and also had twins. These twins are the parents of all living people.

The above and many other reasons of common denominators reasonably consider Igala as one ethnic community. Within the geographic demarcation, the Igala recognizes two main regions: the Idah and 
Ankpa, which could be well described as south-west and north-east of the Kingdom. The settlement and village life of Igala is very coherent, often cohesive, linked together by a variety of interlocking socio-cultural factors.

The ancient town of Idah, the Igala capital which is situated on the river Niger has a symbolic political and social character. The written records and oral tradition from the early part of the nineteenth century exploration indicate that many people's trace their rulers' descent to Idah, where the affairs of this riverine area for many centuries were being controlled from. Although, the activities of the riverine area were in the hands of Igala, the Kingdom cannot be described as riverine Kingdom in the strict sense of the word. This is because a great part of the Igala Kingdom is not aquatic. The reason for such control, as J. Boston $(1968,6)$ noted, was largely due to the organized social systems of the Kingdom. The rich social, cultural as well as organized administrative systems enhanced its influence and demographic assimilation of the neighbouring ethnic groups. The strategic position of the kingdom is a key and significant factor in its historical development and social influences. The geographical position of Igala brought them in contact with many other groups and cultures, including the Ibo, the Yoruba, the Edo-speaking peoples, the Jukun, and the Idoma, to name only the principal groups.

\section{The CORPus Of Life AMONG IgALA}

Beyond the phase of individual life is the community base of human existence. This means that for an individual life to be meaningful, it must be realized in a community; in the community, the individual becomes meaningful towards himself and other people. And this is what Abanuka $(1994,49)$ would mean as: "...the root of one's self-awareness and the desire to give meaning to the fundamental problems of human life and existence is one's self understanding as an individual who realizes oneself in a given community". This aspect of Igala understanding of life as community is shared across many cultures in Africa as also observed by Mbiti $(1991,92)$ : "When an individual suffers, he does not do it alone but the corporate group; when he rejoices, he rejoices not alone but with his kinsmen, his neighbours and his relatives whether dead or living. When he gets married, he is not alone, neither does his wife belong to him alone. So also the children belong to the corporate body of his kinsmen, even if they bear only the father's or mother's name". This further suggests that whatever happens to the individual happens to the society he belongs, and whatever happens to the society happens to the individual as well. It is only in this way that the individual is capable of saying: 'I am, because we are; and since we are, therefore, I am'.

The above significance of individual and the role of the community are further reasoned by Abanuka (48) as forming the indispensable organ of an African society in which "the attainment of meaning takes place in the interiority of the individual. The meaning of the individual's presence in the community comes to its highest point when the individuals realize not only that their life and death are particularly theirs, but also that they must live their life and die their death in the community". This is to stress that the importance of community in Igala does not override the necessity of individual identity; the whole is made out of singles. The reality of a community and its survival as a social institution is enhanced by the contributions of her members as individuals with variety of potentials. This rhymes with Gbadegesin's $(1991,64)$ clarification that, "the usual rendering of this to the effect that the individual in traditional societies is crushed by the almighty presence of the community is not the whole truth. Of course, individuals are valued in themselves and as potential contributors to communal survival....emphasis is placed on usefulness for self and community and not on wealth or strength." Thus, it could be argued that if individual uniqueness were not recognized, how could we have powerful figures?

Furthermore, the importance of individual for community or group set-up is emphasized by the fact that each person bears a specific name, even other than that of his parents. Consequently, current studies of African cultures in terms of dynamism of language and its adherent modus operandi as in folktales, proverbs, riddles and other ways of transmission of knowledge have shown that their usage is closely tied to the role and importance of individual as well as the group.

\subsection{Life as Marriage and Procreation}

One of the important concerns of the Igala is that a person ought to get married so that his name will be carried on. As such, if an Igala person reached the age of marriage and refused to be married 
without any reason, he or she cannot be treated with dignity. They often use the phrase 'carrying on name', which in other words means to 'live on' or simply to be alive. By this, they mean more than merely the bearing of one's name by future descendants. The importance of marriage in Igala society cannot be overemphasized and it is for this reason that many boys on reaching adulthood, do not delay in taking wives. It is because of the importance attached to marriage, that an unmarried adult is not respected in Igala traditional communities. It expresses a concern that if a man was to leave this world without leaving behind any progeny, he would have no status in the spirit world. Therefore, it is a tremendous responsibility for a son to get married in order to make sure that his father has status when he goes into the other world, for without children one is not able to "carry on one's name". This essentially means to have life.

In Igala tradition, personal names are usually given to children. Igala parents regard personal names as very important and they are usually very careful in the choice of names. The factors which influenced parents in the choice of names includes; the condition of birth of the children, belief in reincarnation, the belief in gods or spirits, the influence of infant mortality or death etc.

\subsection{Categories of Death in Igala Religious World}

There is a belief among Igala that man is a sojourner on earth. No matter how long a man lives on earth, he must die one day. There is also a belief that death is a transition from the physical world to 'efojegwu' (the spirit world). Also, there is a belief that when a man dies, his spirit is separated from his body (physical body). When the physical body is buried, it decays, but the soul returns to the owner of breath (God) and the spirit comes back to this world and serves as a benevolent or malevolent one. In the other perspective, death is seen as a kind of spirit; and as a result, it is feared by many people. Among Igala, many words and phrases are used to describe death. If the deceased was old, his or her death could be described as 'going home', 'returning home', 'going to join the ancestors', 'sleeping', etc. However, if the deceased was a young person, his death could then be described as 'being snatched away', 'falling into the hands of the wicked', 'captured by the wicked', etc. Despite the negative emotions generated by these words and phrases, it is believed that life goes on beyond the grave. In other words, death is not a complete destruction of individual. Death in fact opens the way to change one's condition: by it, the human being becomes an ancestor and is fulfilling the destiny by living again in another form. This according to Erny P. $(1981,16)$ means: "being born must therefore be thought of in category of passage. To come here is to leave the beyond; it is to be in transit, to change one's state. Being born here means dying up there and at the end of life the opposite is true: to die here is to be born up there."

In Igala world-view, no one escapes death; human beings are born to die. However, most people wish to live to old age probably up to hundred years. Thus among Igala, there is a very strong belief in destiny, such that everyone is expected to live up to old age. However, death always beckons, it strikes the infant, adolescent, young adult, and old people alike. It is no respecter of any person. Hence in the culture of Igala, death is categorized according to the circumstances and age of the deceased. These various categories include the following:

\subsubsection{Premature Death}

This is the departure of those considered not yet ripe for death at the time they died. The cause of death may be attributed, in most cases, to the evil manipulations of witches and wizards in the family or outside of the family of the deceased.

\subsubsection{Accidental Death}

Pregnant women who pass away during labour, those who have met their death through accident, suicide and drowning come under this category. It is believed that witches and wizards are responsible for such accidental deaths.

\subsubsection{Death at Old Age}

This is the type of death that is cherished by most Igala. It is believed that such individuals have gone home to meet the ancestors. The elaborate burial ceremonies for those who pass on at old age indicate that this category of death is highly valued by members of the society.

\subsection{Causes of Death}

Some causes are associated with death among the Igala people. According to them, the main causes of death are: witchcraft, magic, spirits and the deities. 


\subsubsection{Witchcraft}

It is believed that witches and wizards can cause the death of an individual, sometimes through the use of evil magic. It is strongly believed among Igala that witches can kill or destroy their enemies.

\subsubsection{Magic}

Apart from decisions taken in the coven to harm an individual, and to cause his or her death, there are also powerful or potent magical manipulations often procured by medicine men which are also believed to achieve the same evil effects. Magical preparations may be placed on the door steps of an intended victim. Similarly, such preparations may be prayed on his or her garments to achieve the desired results. It is also believed that dogs, snakes and rats may be sent to strike down an enemy.

\subsubsection{Spirits}

Parents who have died desire decent burial from their children. Such burial ceremonies may or may not be elaborate, depending on the status of the deceased when he was alive. Traditional chiefs and other individuals with titles are often accorded elaborate burial ceremonies. However, well-to-do children sometimes bury their parents with elaborate ceremonies even though such parents were not wealthy when they were alive. It is believed that the spirits of death parents and sometimes of their relatives who have not been properly buried may inflict death on their kinsmen and women.

\subsubsection{The Deities}

According to the tradition of Igala, the deity is believed to protect all the people in the locality. It also takes vengeance on evil doers for offences and crimes committed in secret. People may swear by the deity. In fact, individuals may be tried before the deity for various offences. It may thus be invoked to find out the guilty party. It is believed that the local deities do their work by causing the death of offenders.

\subsection{The Living-Dead in Igala Religious World}

Attah a writer on Igala cosmology and belief-system is of the view that the living dead are the Ibegwu of the ancestral spirits that are highly regarded in Igala traditional society. In the same view Mbiti described the living dead as: A person who is physically dead but alive in the memory of those who knew him in this life as well as being alive in the world of spirits. The Igala people believe in the idea that their ancestors exist in the other world. They also have the belief that if a man is not due for death and is about to be sent to his early grave, the ancestors would fight back to preserve his life. This is one of the reasons why Igala people bury their dead in their homes. This is to assert the belief that by doing so the family has a closer link to their dead ones. Also during a burial ceremony the dead are covered with new clothes because they would use it in the other world. The idea of burying the dead in the family compound also signifies shelter for them which have to be within the family stead. In most festivals, the ancestors are conjured; they are called to attend the festival such that sacrifices in form of foodstuff are prepared during the festival and given to them before the living can partake of it. In events were harvest is been celebrated, the ancestors are given the new crop to eat before the living eat from it. This is significantly so because it is believed that they are the ones responsible for the good soil, rain and sunshine that led to a bumper harvest.

In his contribution, Omale, an Igala elder narrated that among the Igala traditional beliefs; there are two categories of the living dead or the ancestral spirits that are worshipped. These classifications are the form of the Elis and the Egwu afias. Whereas the Elis are the ancestral spirits that neither come out in the form of a masquerade and nor speak, the Egwu afias are sacred masquerades that come out at the request of the people. Naturally and culturally, annual festivals are held for the Egwu afias in which they come out and speak to the people. However, in both categories animal festival are held to commemorate the good deeds of the ancestors to ask for more blessings. This is similar to the commemoration of the Alekwu among the Idoma as noted by Enwa (Seminar paper) which regulates the activities of the living: "Society of ancestors dead or alive are the core regulators of social control among the people. To indicate the serious interaction between the living and the dead, Attah (1989, 48) also submitted that the names of the living dead are given to children who show peculiar characteristics to corresponding ancestor in question. By doing this the memory of the dead is kept alive among the Igala people. 


\subsubsection{Rites and Rituals of the Living-Dead}

The Igala in their beliefs of the living-dead perform certain rites and rituals to appease them. These rites and rituals are observed on different occasions, it could be daily, weekly, monthly or annually. These rites are usually carried out to appease their dead ancestors who are believed to be alive in the other world. Igala ancestral rites and rituals involve sacrifices that are carried out, markings on the body, veneration, dancing, singing and drumming, to appease the living dead, either to watch over and protect them from the hands of the evils as they watch over them in the afterlife. These events could go as a form of festivals and big celebrations. Such rites and rituals when carried out could be in form of celebration of the birth of a child or dedication and mourning the death of a member of the family. If a child is born and is noticed to have traits of a dead member of the family, the child is given the name of that late member of the family in honour of him. Rites and rituals could also be carried out in form of purifying of iniquities like when a woman leaves her home to commit adultery; various forms of sacrifice are performed to cleanse the woman of that iniquity and is usually carried out by her uterine kin. She is cleansed of the ill-luck, her act would bring on her family and husband.

Some times food and drink are offered as a form of sacrifice to appease the living dead. When the dead are angry libations are usually poured to appease them and the necessary ritual is observed to find out the cause of their anger.

Furthermore, when a man dies certain rites and rituals are performed. But, first and foremost the dead must be buried among his peer group within the community household. It is believed he should be buried among his people with new clothes. The new clothes are supposed to cloth him in the afterlife. Before his burial, the oracle is consulted to know whether he was killed or not. If he has no male child, it means that his family line has been terminated, but if he has a male child, it is believed that the male child would assume or take the position as the head of the family and would carry out all conjuration on behalf of the family. If it is that he does not have a male child, the burial would be a pathetic ceremony to signify the end of his lineage. This is done by breaking kolanut to signify his disconnection from the family.

Finally, there is the second burial where all the masquerades would come out to dance for nine days led by Egwu afia which is the agent of the ancestors. It is believed that during the rite, Egwu afia is communing with his ancestors. The third rite in the burial process is the Ogwu-eda. Here a life cock is brutally slaughtered with one stroke of the knife or by strangulation in bare hands to separate the living dead from the world. Except that is done, it is believed that his spirit is still malevolently within the world. When all this have been done the final burial rite is what they call Eloji whereby his grave is locally plastered. Then goat and cows are slaughtered in his honour.

\subsubsection{The Representatives of the Living-Dead}

The representatives of the living dead among the Igalas are usually seen as the intermediaries between them and humans. They come out once in a while to pass message to the people. Some examples according to Ukwedeh $(2003,33)$ are: Masquerade $\left(A m^{\prime}\right.$ 'egwu), The seer (Am'abifa) and the priests (Am'atama)

Masquerade (Am' egwu): The masquerades or $A m$ 'egwu, which could belong to families, ward or lineages, the village or town, communities as a whole, were ostensibly the property of the chief of the town, the Onu ane. Masquerades are highly influential in Igala society. In his submission, Ukwuede (34) opines that apart from their roles in entertainment, social and political purposes, masquerades function mostly as agents of the living dead. Masquerades used for such purposes include the Ekwe, the Abule, the Obajadaka, the Olagenyi and Ukpokwu. Some masquerades mentioned above publicly flogged erring, or offenders of the traditions or those who go against their ancestors. Masquerades such as Egwu-afia, the Abule, and the Amuda, publicly rebuke thieves, adulterers, and the indolents by disclosing their names cursing and warning them depending on what message they are being asked to deliver by the spirits. The Ajamalede in particular uses words that are loaded with facts and meaning to psychologically chastise offenders. In short, Masquerades are used as mouthpiece of the gods, spirits and the living dead as well as being agents of social control as noted by Miachi in various instances.

The Seers (Am'abifa): The use of the Ifa priests as agents of the gods, spirits and the living dead is also common among the Igala. The Ifa priest is mainly there to forecast the future. Thus for Ukwuede 
(Ibid, 34), the Am'abifa are regarded as people who could use their unseen forces to any end. Consequently, the Igala society is versed with various kinds of Ifa oracles such as Ifa anwa, Ifa elanyi, the Ifa onu, Ifa Odu etc. The Ifa priests are known for foreseeing and passing messages from the gods, spirits, and the living dead. Even the highest officials in the community are in some respects, religiously sub-ordinate to the Am'abifa.

The Cult Priests (Am'atama-Ebo): The Cult priests among Igala are mainly for the purposes of worship and offering of sacrifices to the deities, the Ebo. It is part of the Igala belief that certain types of bad behaviours such as stealing, lying and murder are not tolerated by the gods and the living dead. This belief, according to Ukwuede (Ibid, 37), also gives the priests (atama-ebo) to bring such people to swear and be reconciled to the gods and the spirit. Thus, they are respected by the public, since they represent the gods. For examples, the system recognizes swearing over vicious fetishes which can bring two contending parties to the priest; understanding the offending party, as would be determined by the god would ensure that his property would become that of the gods, until redeemed. This redemption involved payment in cash or kind or both of some property to the priest in order to appease the god. The priest plays a major role in standing as a representative of the god, spirit, and the living dead.

\subsubsection{Harmony and Communion with the Living Dead}

Communication with the living dead is mostly through divination of kolanut with four lobes thrown to the living dead through his Okwute (staff of office). Because even after he dies, his Okwute is kept as a link for his request or message to his family or clan or community. In cases where he needs to be appeased with sacrifice, he communicates through his Okwute. Another mode is through the Ifa oracle whereby the priests consult the living dead or message is been passed through the priest to the family or community.

\subsubsection{The Mediums of the Living-Dead}

Egwu afia:- This is the masquerade that is in-charge of all other masquerades in a typical Igala society. It comes out rarely: it only comes out when the ancestors have message to pass to the people (community or individuals). Along with Egwu afia, there are other masquerades that partake in the commercial field of working with the ancestors, such as Igbalaja, Obale, Akulaku etc; together these masquerades serve as mediums of communications by the ancestors.

Okwute: - As previously noted, this represents the staff of authority of elders. It is another medium used by the living dead to communicate with their family members an earth. The Okwute is of a great significance among the Igala. It serves as the staff of office which the ancestors of the family possessed while they were alive. The Okwute is kept by the family head and is used to commune with the ancestors of the family.

\subsubsection{The Interactions of the Living-Dead with the Igala People}

In the modern society, the Igala are mostly connected with the living dead through social interactions, especially when they come together to commemorate their dead through festivals or burial ceremonies. However, Igala in our modern society are gradually forgetting the importance of maintaining connection with their dead. In ancient times, sacrifice was usually carried out along with prayer daily to appease their ancestors. The Igala of today principally interact with their dead through the means of Festivals and Burials.

\subsection{Festivals}

During festivals in the Igala society, sacrifices and prayers are made to appease the living dead as well as to be able to interact with them. This mode of interacting with the living dead is the most popular means by which Igala commune with their dead. During this festival, masquerades are brought out by each clan to entertain the audience. The masquerades compete among themselves. The best dancer is identified and a prize is awarded to it by the eldest person or the clan head. This method of communing with the dead is widely practiced. In this way, it is believed that the masquerades that won the competition had the presence of the ancestors of the clan which it represented around it. 


\subsection{Burial}

It must be acknowledged that this means of communing with the dead has drastically slowed down due to the influence of Christianity and Islam which burial systems are cheaper. It is only used when an elderly person within the community dies. Here masquerades are equally brought out to honor the memory of the dead and to also interact with the dead. The masquerade is believed to guide the dead into the ancestral realm. As such, the masquerade goes away as soon as the burial is over. In most villages this practice is been used to accompany elders who have lived well and are soon to be considered among the ancestors.

\section{CONCLUSiON}

Amongst Igala today the idea of the living dead and interaction with the living has slowed down due to the influence of Christianity and Islam. However, the traditional giving of names of dead members of the family to children amongst others is indicative of strong belief that the dead are in some way living. The giving of names to their children signifies that the dead are still being remembered in the future. Most Igala children are given names of their grand-fathers, great grand fathers and even great uncles or aunts in memory of them.

An average Igala person would give such names to their sons/daughters that show some peculiars characteristics of the living-dead. In some cases when a child is born, oracles are consulted to know which of the ancestors is reincarnated as the "god of the child". This belief is not outdone by Christianity and Islam. Both Christians and Muslims alike give traditional names that their forefathers or mothers used while they were alive. Examples of such names are Iye (Mother) and Atta (father). This is to show their understanding that the living-dead deserve recognition and so should be revered in the children.

The implication of losing communication with the living dead is said to come with its own consequences. With the advent of Christianity and Islam, the rate at which people abandon the tradition of their forefathers has accelerated so much so that sacrifices are no longer being carried out as such again to appease the dead. This is because; such practices are being viewed as idolatry due to the monotheistic nature of Christianity and Islam. Children born in this era have started losing touch with this tradition and view it as fetish. The loss in the tradition of regard for the ancestors also affects the respect and honour due to elders in Igala society of today.

\section{REFERENCES}

[1] ABANUKA, B., (1994), A New Essay on African Philosophy, Enugu: Snaap Press

[2] ADAMU, M., (1993), The Social and Cultural Heritage of the Igala, Ilorin: Matami

[3] ADASU, M.O., (1985), Understanding African Traditional Religion, London: Dorset

[4] ATTAH, A.,(1989), An Introduction of Igala Cultural Studies (Katsina-ala: Epari Printers

[5] - - , , (2001) Igala Cosmology and Belief System (a public lecture)

[6] BOSTON, J. S. (1968), The Igala Kingdom, Oxford: University Press.

[7] ENWA, J. A., (2005), The Institution of the Alekwu Among the Idoma (a seminar paper)

[8] ERNY, P., (1981), The Child and His Environment in Black Africa, Oxford: University Press

[9] GBADEGESIN, S., (1991), African Philosophy - Traditional Yoruba Philosophy and Contemporary African Realities, New York.

[10] MBITI, J. S., (1999), African Religions and Philosophy, New York: Anchor books

[11] - - , , (1991), Introduction to African Religion, Second Edition, Oxford: Heineman.

[12] MEDELSON, .J., (1993), God, Allah and Juju: The Igala Belief System, Boston: Beacon

[13] OKWOLI, P.E., (1973), A Short History of Igala, Ilorin: Matami.

[14] - - - Introduction to Igala Traditional Religion, Anyigba: Pastoral Press.

[15] OKPE, N., (2005) Social and Cultural Identity of an African Society: The Igala People of Nigeria. Frankfurt am Main: Peter Lang.

[16] OCHALA, A., (2001), The belief system among the Igala people of Kogi state (A key note address at Egbe festival Egume

[17] OMALE, I., (2012), Oral interview with clan head in Akpagidigbo in Ofu L.G.A. 
[18] SETON, R.S., (1930), Notes on the Igala Tribe. Journal of the African Society, vol. XXIX, London

[19] UKWUEDE, .J. N., (2003), History of the Igala Kingdom, Zaria: ABU Press

\section{AUTHOR'S BIOGRAPHY}

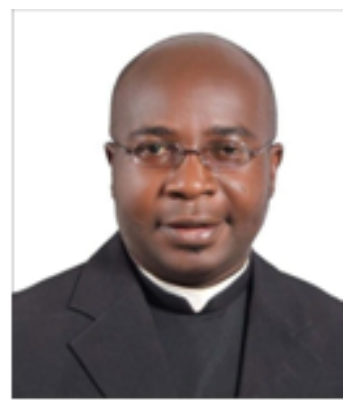

Dr. Okpe, Nicholas Ojoajogwu is a Catholic Priest and a Seniour lecturer of Ethics in Humanities within the ambient of Religion and Society, Department of Religious Studies, Kogi State University, Anyigba, Kogi State - Nigeria. He obtained his degrees from Universities in Germany where he studied between 1994 and 2007. He has authored about fourteen books and published several articles in both local and international journals. His $\mathrm{PhD}$ thesis titiled: "The social and cultural Identity of an African Society - The Igala People of Nigeria", was published concurrently in Franfurt (Germany), London (United Kingdom) and New York (USA) in 2006.

Citation: Okpe Nicholas Ojoajogwu, Ph.D. "The Corpus of Life and the Phenomenon of Death in a Traditional Igala (African) Religious Society" International Journal of Humanities Social Sciences and Education (IJHSSE), vol 5, no. 8, 2018, pp. 35-42 doi: http://dx.doi.org/10.20431/2349-0381.0508006.

Copyright: () 2018 Authors. This is an open-access article distributed under the terms of the Creative Commons Attribution License, which permits unrestricted use, distribution, and reproduction in any medium, provided the original author and source are credited. 